\title{
Amebiasis Presenting as Acute Appendicitis: Case Report
}

\author{
Wilson Onuigbo ${ }^{1 *}$ and Obumneme Ekwueme ${ }^{2}$ \\ ${ }^{1}$ The University of Nigeria Teaching Hospital, Nigeria \\ ${ }^{2}$ Oko Community Hospital, Nigeria
}

*Corresponding author: Wilson Onuigbo, The University of Nigeria Teaching Hospital, Enugu, Nigeria, Email: wilson.onuigbo@gmail.com

Submission: 眥 March 8, 2018; Published: 眥 March 15, 2018

\begin{abstract}
The presentation of amoebiasis as acute appendicitis is a rarity. In recent years, case reports of this phenomenon appeared in the literature from countries as far apart as Japan, India, Egypt, and Kuwait. Therefore, this paper reports a Nigerian case whose age was typical.
\end{abstract}

Keywords: Appendix; Appendicitis; Amoeba; Nigeria

\section{Introduction}

Amoebiasis presenting as acute appendicitis is a rarity. A search of the literature revealed recent accounts of individual cases from countries as far apart as Japan, India, Egypt, and Kuwait [1-4]. Therefore, a Nigerian case is deemed to be worthy of documentation. Histopathologic examination revealed the unexpected presence of Eutameba histolytica instead of the ordinary inflammation.

\section{Case Report}

A 30-year-old man of the Igbo ethnic group attended the Oko Community Hospital complaining of pain in the abdomen with nausea since 2 days [5]. He was examined by one of us (OE). There was classical tenderness in the right iliac fossa, the Rovsing's sign being positive. At the operation, the appendix showed adhesions and was removed. On receipt by the co-author (WO), it was a diminutive $4 \mathrm{~cm}$ appendix with fecal matter. On microscopy, there were luminal pus cells as well as typical E histolytica parasites showing ingested red blood corpuscles. There was uneventful recovery following metronidazole treatment.

\section{Discussion}

In a Japanese contribution, the amebic element was complicated by HIV-1-infection [6]. This was not the issue in our case. Turkish authors obtained a total of 174 cases of amebic appendicitis using the PubMed and MEDLINE databases [7]. The mean age of the patients was 23.5 years (range 2 months-83 years). In other words, our local patient aged 30 years is typical. Moreover, male preponderance is typical. Birmingham (UK) authors stressed that the establishment of a histopathology data pool improves epidemiological analysis [8]. Indeed, it was such a Regional Laboratory that helped matters in our patient. Incidentally, there was some debate in the UK about the usefulness of a central laboratory in terms of distant researchers [9]. As argued elsewhere, the usefulness is clear especially in a developing community [10]. Furthermore, USA authors concluded from a total of 93 reported cases that "The condition is suspected clinically whenever a cecum of hard, 'cardboard-like' consistency is discovered" [11]. Our experience of the cecum was not of such a consistency.

\section{References}

1. Ito D, Hata S, Seiiciro S, Kaminishi M, Teruya M, et al. (2014) Amebiasis presenting as acute appendicitis: Report of a case and review of Japanese literature. Intl J Surg Case Rep 5(12): 1054-1057.

2. Krishna M (2016) Amoebic chronic appendicitis: A rare entity. J Pathol Nepal 6: 1046-1047.

3. Hegazi MA, Patel TA (2013) Acute amoebic appendicitis: Case reports and review of parasitic appendicitis. J Pediat Infects Dis Soc 2(1): 80-82.

4. Singh NG, Mannan AASR, Kahvic M (2010) Acute amebic appendicitis: Report of a rare case. Indian J Pathol Microbiol 53(4): 767-768.

5. Basden GT (1996) Niger Ibos.

6. Kobayashi T, Watanabe K, Yano H, Murata Y, Igari T, et al. (2017) Underestimated amoebic appendicitis among HIV-1-infection individuals in Japan. J Clin Microbiol 55(1): 313-320.

7. Otan E, Akbulut S, Kayaalp C (2013) Amebic acute appendicitis: Systematic review of 174 cases. World J Surg 37(9): 2061-2073.

8. Macartney JC, Rollaston TP, Codling BW (1980) Use of a histopathology data pool for epidemiological analysis. J Clin Pathol 33(4): 351-353.

9. Lilleyman J (2002) From the president. Bull Roy Coll Pathol 117: 2-3.

10. Onuigbo WIB, Mbanaso AU (2005) Urban histopathology service for a remote Nigerian hospital. Bull Roy Coll Pathol 132: 32-34.

11. Guzman-Valdivia G (2006) Acute amebic appendicitis. World J Surg 30(6): 1038-1042. 
Creative Commons Attribution 4.0 International License

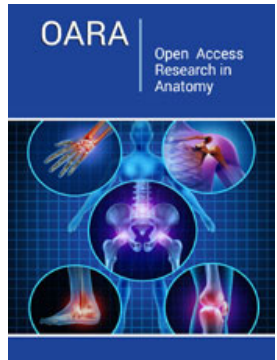

\section{Open Access Research in Anatomy}

\section{Benefits of Publishing with us}

For possible submissions Click Here Submit Article

- High-level peer review and editorial services

- Freely accessible online immediately upon publication

- Authors retain the copyright to their work

- Licensing it under a Creative Commons license

- Visibility through different online platforms 